\title{
Quality and generation rate of solid residues in the boiler of a waste-to-energy plant
}

\author{
Allegrini, Elisa; Boldrin, Alessio; Jansson, S.; Lundtorp, K.; Astrup, Thomas Fruergaard
}

Published in:

Journal of Hazardous Materials

Link to article, DOI:

10.1016/j.jhazmat.2014.01.048

Publication date:

2014

Document Version

Peer reviewed version

Link back to DTU Orbit

Citation (APA):

Allegrini, E., Boldrin, A., Jansson, S., Lundtorp, K., \& Astrup, T. F. (2014). Quality and generation rate of solid residues in the boiler of a waste-to-energy plant. Journal of Hazardous Materials, 270(4), 127-136.

https://doi.org/10.1016/j.jhazmat.2014.01.048

\section{General rights}

Copyright and moral rights for the publications made accessible in the public portal are retained by the authors and/or other copyright owners and it is a condition of accessing publications that users recognise and abide by the legal requirements associated with these rights.

- Users may download and print one copy of any publication from the public portal for the purpose of private study or research.

- You may not further distribute the material or use it for any profit-making activity or commercial gain

- You may freely distribute the URL identifying the publication in the public portal

If you believe that this document breaches copyright please contact us providing details, and we will remove access to the work immediately and investigate your claim 
Accepted for publication in Journal of Hazardous Materials

\title{
Quality and generation rate of solid residues in the boiler of a Waste-to-Energy plant
}

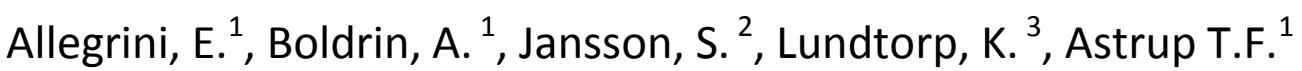 \\ ${ }^{1}$ Department of Environmental Engineering \\ Technical University of Denmark \\ Kgs. Lyngby, Denmark \\ ${ }^{2}$ Department of Chemistry \\ Umeå University \\ SE-901 87 Umeå, \\ Sweden \\ ${ }^{3}$ Babcock \& Wilcox Vølund A/S
}

"NOTE: this is the author's version of a work that was accepted for publication in Journal of Hazardous Materials. Changes resulting from the publishing process, such as peer review, editing, corrections, structural formatting, and other quality control mechanisms may not be reflected in this document. Minor changes may have been made to this manuscript since it was accepted for publication. A definitive version is published in Journal of Hazardous Materials, vol 270, pp 127136, doi: http://dx.doi.org/10.1016/j.jhazmat.2014.01.048" 


\begin{abstract}
The Danish waste management system relies significantly on waste-to-energy (WtE) plants. The ash produced at the energy recovery section (boiler ash) is classified as hazardous waste, and is commonly mixed with fly ash and air pollution control residues before disposal. In this study, a detailed characterization of boiler ash from a Danish grate-based mass burn type WtE was performed, to evaluate the potential for improving ash management. Samples were collected at ten different points along the boiler's convective part, and analysed for grain size distribution, content of inorganic elements, polychlorinated dibenzo-p-dioxins and dibenzofurans (PCDD and PCDF), and leaching of metals. For all samples, PCDD and PCDF levels were below regulatory limits, while high $\mathrm{pH}$ values and leaching of e.g. $\mathrm{Cl}$ were critical. No significant differences were found between boiler ash from individual sections of the boiler in terms of total content and leaching, indicating that separate management of individual ash fractions may not provide significant benefits.
\end{abstract}

Keywords: Waste-to-Energy; boiler ash; PCDD/F; leaching.

\title{
Abbreviations
}

\begin{tabular}{|c|c|}
\hline WtE & waste-to-energy \\
\hline PCDD and PCDF & polychlorinated dibenzo-p-dioxins and dibenzofurans \\
\hline $\mathrm{CHP}$ & combined heat and power \\
\hline FGC & flue gas cleaning \\
\hline APC & air pollution control \\
\hline TEF & toxicity equivalency factor \\
\hline TEQ & toxic equivalent \\
\hline RSD & relative standard deviation \\
\hline ANC & acid neutralization capacity \\
\hline BA & boiler ash \\
\hline
\end{tabular}




\section{Introduction}

Energy recovery from waste plays an important role in most modern waste management systems. In Denmark, close to 30 Waste-to-energy (WtE) plants incinerate approximately $3.3 \mathrm{Mt}$ of waste $[1,2]$. The majority of these WtE plants are combined heat and power (CHP) units, providing $4.5 \%$ and $20 \%$, respectively, of electricity and district heating production in Denmark [3]. WtE plants generate solid residues of different types: non-hazardous residues discharged from the furnace (bottom ash that can be utilized in construction works), and hazardous residues generated in the flue gas cleaning (FGC) system (i.e. fly ash and air pollution control residues, APC) and the energy recovery system (i.e. boiler ash, BA). While metal recovery and utilization of bottom ash may potentially provide an income for the WtE facilities, disposal of the hazardous residues (FGC residues and $\mathrm{BA}$ ) may be more critical and expensive [4]. The production of BA typically ranges between 2 and $12 \mathrm{~kg}$ per $\mathrm{t}$ of waste incinerated [5]. In many facilities, BA are collected together with the FGC residues in order to minimize the number of residues output streams, but other handling options are also practised (e.g. [6]).

Although a range of important gas-particle reactions occur within the boiler section, existing literature characterizing BA in detail is very scarce. Currently, existing studies have distinguished only between BA-from the evaporator/ superheater and BA from the economizer (all individual sections of the boiler system in a waste incinerator), e.g. as reported in Chandler et al. [7]. BA has mainly been studied in relation to fouling and corrosion processes, and the formation of persistent organic pollutants such as polychlorinated dibenzo-p-dioxins and dibenzofurans (PCDD and PCDF). Some studies investigated the evolution of PCDD/F levels within the boiler, analysing PCDD/F in samples collected from up to 6 different points along the boiler [8-10], thereby providing evidences of PCDD/F formation in the temperature range of $370-490^{\circ} \mathrm{C}$. Yang et al. [11] provided a more detailed characterization of BA sampled at the first superheater (flue gas temperature from $\left.600-700^{\circ} \mathrm{C}\right)$, at the second superheater $\left(500-600^{\circ} \mathrm{C}\right)$ and at the end of the economizer, where all BA was mixed together into one flow. The ash from the first superheater had higher contents of sulphates and metals compared with the second superheater, while the largest amounts of metals were found in the mixed sample from the economizer because of more metals were condensed to particles at the lower temperatures towards the end of the boiler. Phongphiphat et al. [6] analysed samples collected at three different points in the boiler: superheater; evaporator; economizer. An enrichment of sulphur and zinc was found in the superheater ash compared with evaporator and economizer ashes, whose composition was similar to bottom ash, except for enrichment of alkali metals. Other authors [12-14] have investigated the possibility of optimizing BA management (e.g. as additive in cement mortar or as source of recoverable metals), but no satisfactory results have been achieved. Very few studies have addressed the leaching properties of BA (e.g. [7, 11]), although the leaching may be decisive for the final disposal of the ashes.

BA quality is expected to depend extensively on plant operating conditions, input waste composition and boiler configuration [7]. However, as temperature and gas phase composition develop throughout the boiler, BA characteristics can potentially vary considerably from one end of the boiler system to the other, as also indicated by existing literature. Detailed characterization studies for BA, however, are missing. Detailed data for variations in ash composition, leaching properties, and contents of PCDD/F are needed as basis for decision-making regarding potential alternative management options for $\mathrm{BA}$ and for better understanding of ash formation mechanisms as a basis for improving future furnace and boiler section design. 
The aim of this study was to provide a detailed characterization of generation rates and quality of BA generated at a full scale WtE plant. This was done by: i) sampling ash in ten horizontal sections of the boiler; ii) characterizing the samples with respect to grain size distribution, chemical composition, concentrations and profiles of PCDD/F and leaching behaviour; and iii) evaluation of the potential for alternative management of individual BA fractions.

\section{Materials and methods}

\subsection{The WtE plant of the study}

BA samples were collected at furnace line 4, at the $27 \mathrm{MW}_{\text {th }}$ AffaldPlus WtE plant, Næstved, Denmark. Line 4 is a grate-based mass burn plant with air-cooled Dynagrate, with a boiler consisting of 3 vertical radiant passes followed by a horizontal superheater/economizer section. The plant has a capacity of $8 \mathrm{t} / \mathrm{h}$ at a lower heating value of $12 \mathrm{GJ} / \mathrm{t}$, producing $23 \mathrm{MW}$ steam at $405^{\circ} \mathrm{C}, 52$ bar. The plant receives mixed municipal solid waste from households, local industries, recycling stations, and the commercial/institutional sector. A schematic figure of the configuration of the horizontal part of the boiler is shown in Figure 1. The boiler can be divided in ten sections (named Sec1 to Sec10), each of them corresponding to a bottom hopper for ash discharge. The different sections vary in function, temperature and piping configuration. Following the flue gas flow within the horizontal part of the boiler, the first section is a protective evaporator screen with a pitch of $200 \mathrm{~mm}$ (the distance between the tubes) and an expected surface temperature of approximately $350^{\circ} \mathrm{C}$. The following four sections (Secs2-5) function as a superheater. The pitch is $200 \mathrm{~mm}$ in Sec2, while it decreases to $160 \mathrm{~mm}$ in Secs3, 4 and 5. The surface temperature varies from $310^{\circ} \mathrm{C}$ to $450^{\circ} \mathrm{C}$. Sec 6 contains no piping and is followed by the economizer which includes the remaining four sections. In the economizer, the pipe pitch is $100 \mathrm{~mm}$, and the temperature at the surface of the tubes ranged from $150^{\circ} \mathrm{C}$ to $310^{\circ} \mathrm{C}$ from Sec 7 to Sec 10 . The flue gas temperature within the boiler drops from a temperature of approximately $700^{\circ} \mathrm{C}(\mathrm{Sec} 1)$ to $500^{\circ} \mathrm{C}(\mathrm{Sec} 4), 340^{\circ} \mathrm{C}$ (Sec7) and $160^{\circ} \mathrm{C}(\mathrm{Sec} 10)$. All tube bundles are equipped with rapping gears that activate automatically for the shedding of the pipes. During the sampling, rapping gears were activated every 46 minutes.

\subsection{BA sampling}

BA samples were collected from the ten horizontal sections of the boiler. At the end of each hammering cycle, samples were extracted from the bottom of the hoppers, using glass plates for Sec3 to Sec10, and metallic plates for Sec1 and Sec2 due to the high temperatures in these sections. Two separate sampling campaigns were carried out: one-day sampling campaign; and a three-day (Day1, Day2 and Day3) sampling campaign. During the sampling periods, ashes were collected and weighed continuously. The collected material was kept separately for individual sections and sampling days; primary sample amounts ranged between 2.5 and $22 \mathrm{~kg}$ for each section. Each primary sample was mass-reduced representatively by means of a riffle-splitter (Rationel Kornservice RK12, Esbjerg, Denmark), to obtain laboratory samples [15]. The results regarding Sec10-Day1 were excluded from the calculations due to clogging problems in the hopper during sampling. Throughout the paper, focus is placed on the second sampling campaign, as this campaign involved sampling during three consecutive days, generally longer sampling times, and optimized collection procedure. While the first sampling campaign was included mainly to test experimental procedures, the results from this campaign are included in the discussion when 
possible. Differences between the two sampling campaigns are reported in Table A.1 in Appendix $A$, as well as the results from the first campaign.

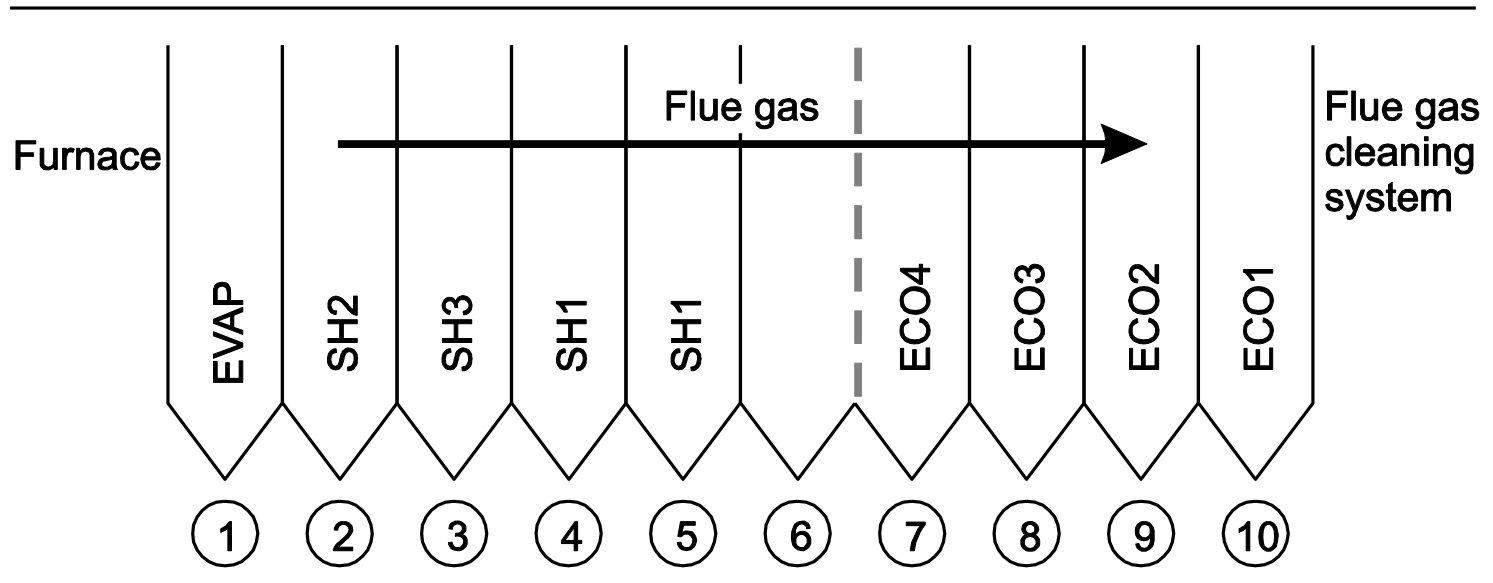

Figure 1. Schematic representation of the convective part of the boiler of Line 4 of the AffaldPlus WtE plant. Circled numbers represent the ash sampling points location. The dotted line separates the economizer from the rest of the boiler [EVAP: protective evaporator screen; SH: superheater; ECO: economizer]

\subsection{Analytical methods}

\subsubsection{Grain size distribution and chemical characterization}

Samples of $100 \mathrm{~g}$ were used for grain size distribution analyses following the standard procedure ASTM C136 [16], using stainless steel sieves with mesh size going from $2 \mathrm{~mm}$ to $0.063 \mathrm{~mm}$. To analyse the content of inorganic elements, dry samples were reduced to powder manually in a ceramic mortar; $0.2 \mathrm{~g}$ were used for microwave-assisted digestion [Anton Paar, Multiwave 3000] with $\mathrm{HNO}_{3}, \mathrm{HCl}, \mathrm{HF}$ and $\mathrm{H}_{3} \mathrm{BO}_{3}$ [17], and subsequent analysis in ICP-OES [Varian MXP]. The contents of $\mathrm{Hg}$ and of the water soluble $\mathrm{Cl}$ were determined at an external accredited laboratory (ALS Scandinavia, Luleå, Sweden) following the standards procedures [18, 19]. Every sample was digested and analysed in duplicate.

\subsection{2. $P C D D / F$ analyses}

Internal standards of isotopically labelled tetra-to octachlorinated PCDDs were added to the ash samples (sample amounts of 8.47-14.53 g in cellulose extraction thimbles). Acetic acid was added and allowed to soak in for one hour, and the samples were then soxhlet extracted with toluene.

The sample extracts were evaporated and the resulting concentrated extracts divided into two $50 \%$ parts. One of the $50 \%$ extracts was prepared for the determination of PCDD and PCDF, according to a clean-up scheme using a multilayer silica column, an alumina column, and an AX21 carbon: Celite 545 column. Finally, recovery standards were added. All laboratory work was performed according to validated methods, which are described in detail by Liljelind et al. [20].

The instrumental analysis was performed by high-resolution gas chromatography-mass spectrometry (GC-HRMS), using a Waters AutoSpec ULTIMA NT 2000D mass spectrometer (Micromass UK Limited, Manchester, UK) and an Agilent 6890N Network GC System gas chromatograph, using a J\&W Scientific DB-5MS $(60 \mathrm{~m}, 0.25 \mathrm{~mm}$ id, $0.25 \mu \mathrm{m})$ capillary column. The mass spectrometer was operated in electron impact ionization/selected ion monitoring mode, and analytes were quantified using the isotope dilution technique. Target analytes were identified by 
comparing: (i) their retention times with those of quantification congeners in standard mixtures; and (ii) PCDD/F GC-MS chromatograms published by Ryan et al. [21].

Six lab blanks were analysed, and found to be below $10 \%$ of the sample concentrations. The concentrations of target analytes were calculated on a molar basis and normalized to $1 \mathrm{~atm}, 0^{\circ} \mathrm{C}$, dry gas and $11 \% \mathrm{O}_{2}$. In this study, individual quantifications have only been made for the congeners that have a toxicity equivalency factor (TEF) assigned to them; i.e. the 2,3,7,8substituted congeners. Toxic equivalent (TEQ) concentrations were calculated based on the WHOTEF values revised in 2005 [22].

\subsubsection{Leaching tests}

The element release from the BA material was assessed through two leaching tests. Firstly, the compliance leaching test EN 12457-1 [23] - required by Danish and EU legislation [24, 25] (limit values are reported in Table A.4) - was performed on $175 \mathrm{~g}$ test samples, at L/S $2 \mathrm{l} / \mathrm{kg}$ and with 24 h mixing time. Secondly, the pH static leaching test EN 14997 [26] was used to characterize the leaching behaviour of the material at different $\mathrm{pH}$ conditions $(\mathrm{pH} \mathrm{12,7}$ and 4). Three samples of 60 g were mixed for $48 \mathrm{~h}$ with distilled water and $\mathrm{HNO}_{3}$ or $\mathrm{NaOH}$, achieving an $\mathrm{L} / \mathrm{S}$ of $10 \mathrm{l} / \mathrm{kg}$. The material was maintained automatically and continuously at the pre-determined $\mathrm{pH}$ value. The eluate from the two leaching tests was filtrated through $0.45 \mu \mathrm{m}$ membrane filters and analysed for $\mathrm{pH}$ and conductivity [PHM210 and CDM210 MeterLab]. The eluate was divided into two: one was acidified using concentrated $\mathrm{HNO}_{3}$ and analysed through ICP-OES [Varian MXP], whose accuracy was controlled with multi-element standard solutions [Inorganic Ventures CCS-5 and DTU-2,-5]; the other was analysed by means of potentiometric titration with $\mathrm{AgNO}_{3}$ to measure the concentration of chloride.

\section{Results and discussion}

\subsection{Ash production and grain size distribution}

BA production was calculated to be $410-540 \mathrm{~kg} / \mathrm{d}$, corresponding to $2-3 \mathrm{~kg}$ per $\mathrm{t}$ of the input waste, in agreement with the literature [5]. The distribution among the ten horizontal sections is reported in Figure 2. The ash production was consistent throughout the three sampling days. The largest ash production was found at Sec7 (i.e. $89 \pm 18 \mathrm{~kg} / \mathrm{d}$ ), followed by Sec9 (i.e. $60 \pm 6 \mathrm{~kg} / \mathrm{d}$ ) and Sec10 (i.e. $65 \pm 7 \mathrm{~kg} / \mathrm{d}$ ). The production at Sec7 can be a result of a combination of flue gas flow conditions and condensation mechanisms. Sec7 represents the beginning of the economizer, and the sharp increase of ash deposition can be explained by the combination of a section without tube bundles in the flue gas flow (i.e. Sec6), followed by the dense (pitch $100 \mathrm{~mm}$ ) tube bundle of the economizer. Moreover, the low temperature in the economizer may lead to homogeneous condensation [27], which seems to be the prevalent ash formation mechanism in the economizer. Condensation is also believed to contribute significantly to deposit formation in Sec1 and Sec2, where the hot flue gas $\left(700^{\circ} \mathrm{C}\right)$ meets the colder tubes of the protective evaporator screen $\left(350^{\circ} \mathrm{C}\right)$, thereby creating regions of high local vapour pressure for salt species (i.e. $\mathrm{NaCl}, \mathrm{KCl}$ ) and other species containing $\mathrm{Pb}, \mathrm{Zn}$ and $\mathrm{Sn}$. In addition, inertial impaction is supposedly also an important deposit formation mechanism at Sec1 and Sec2, as indicated by both the larger share of coarse particles in BA originating from these sections (Figure 3), and the presence of 'shell-like' fragile deposits fragments in the collected samples. Inertial impaction can form 'shell-like' coarse-grained deposits on the upstream side of the pipes, which detach during the shedding [27]. During the first sampling campaign (see Fig.A.1), a production peak at Sec7 was also observed. However, in that 
sampling campaign the sections presenting the greatest production were Sec1 and Sec2. An explanation for the different production rates between the two campaigns can be found in the operating conditions of the plant (see Table A1). Variations in the input waste (e.g. higher heating value) and the higher dry flue gas flow measured during the first sampling campaign can result in a greater amount of particles carried by the flue gas from the furnace to the boiler, and thus an increased amount of ash falling in the first sections.

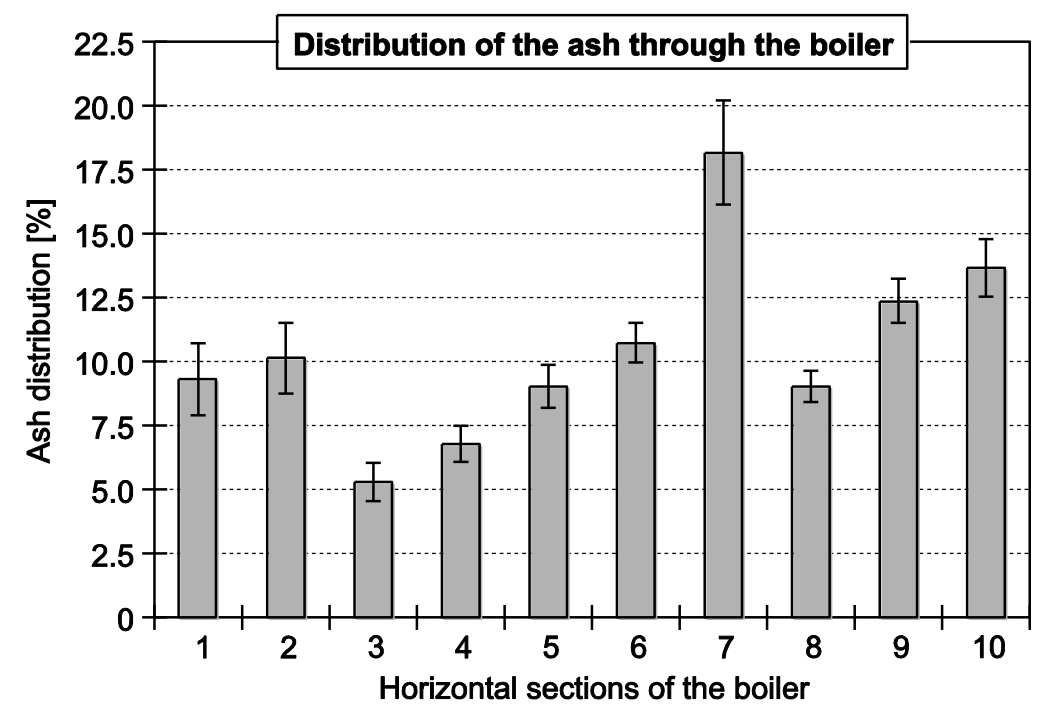

Figure 2. Contribution (\%) of different sections to BA production. The error bars represent $\pm 1 \sigma$ calculated on the samples from the three days.

Figure 3 shows the grain size distribution of ash samples from different sections. Results are presented as an average for the three days, with RSD being below $10 \%$ for most of the sections and grain sizes. Exceptions were Sec1, Sec 8 and Sec9, where the RSD reached values up to $30 \%$ for the cumulative mass passing through the $0.063 \mathrm{~mm}$ sieve. According to the unified soil classification system of the ASTM [28], the residues have a grain size distribution similar to 'sand with fines'. Sec1 presented the greatest share of particles above $1 \mathrm{~mm}$ (up to 14\%), followed by Sec2 and Sec5, while Sec10 had the largest share of fines. The $D_{50}$ values ranged between 0.130 $\mathrm{mm}$ (Sec5) and $0.09 \mathrm{~mm}$ (Sec10). The lowest share of particles below $0.125 \mathrm{~mm}$ was recorded in Sec6, where no tube bundles in the flue gas are present, thereby reducing the formation of ash both by condensation and diffusion impaction mechanisms, owing to Brownian and Eddy forces. Similar results were obtained during the first sampling campaign (see Fig.A.2), but the share of fine particles was found to be generally lower, with values of $D_{50}$ ranging between 0.115 and $0.2 \mathrm{~mm}$.

\subsection{Chemical characterization}

\subsubsection{Inorganic constituents}

Table 1 presents the average chemical composition of BA from the ten horizontal sections. The RSD between duplicates (not reported in Table 1) was below $10 \%$ for most of the samples, with the exception of a few samples showing RSD above $20 \%$ for $\mathrm{Cr}$, Mo and $\mathrm{Ni}$. Recovery of $\mathrm{Cr}$ during digestion was below $72 \%$, meaning that results are affected by great uncertainty. 


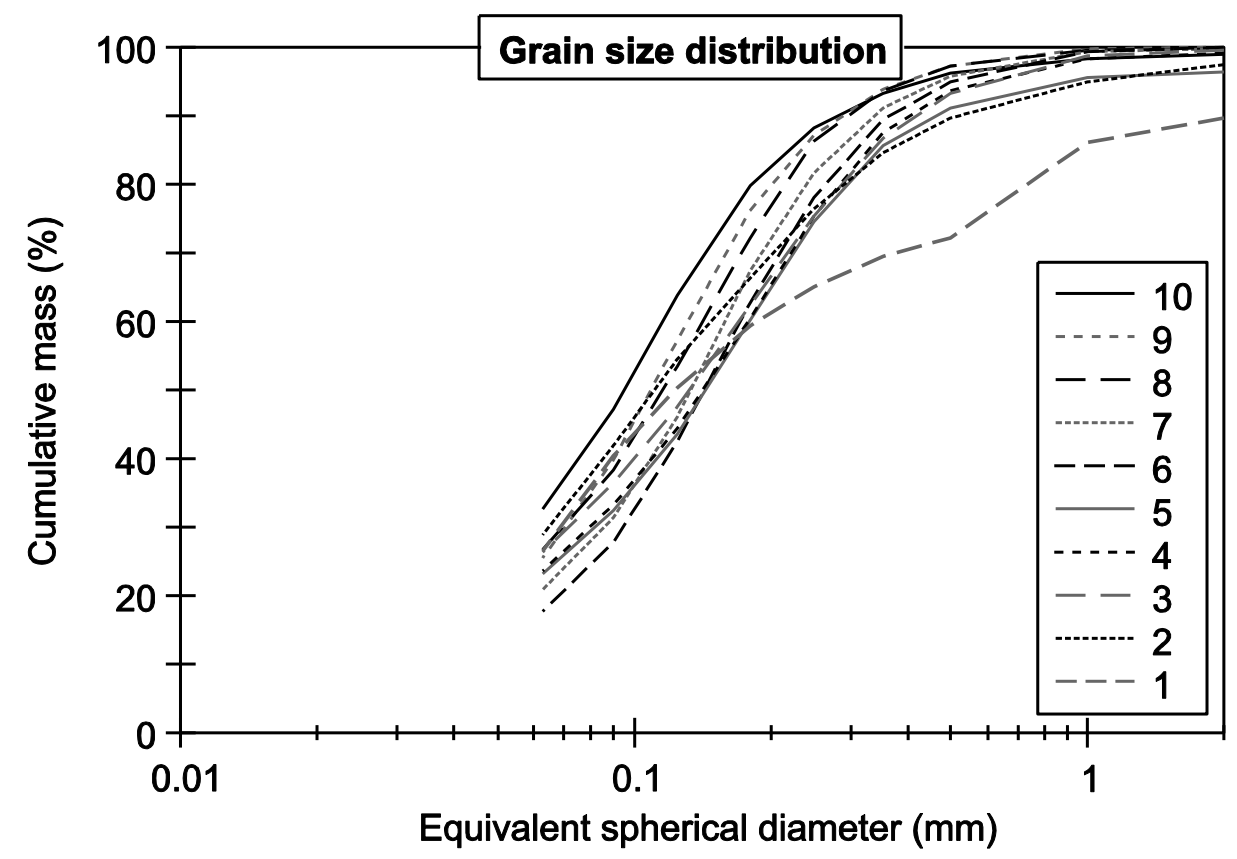

Figure 3. Grain size distribution (\% of cumulative mass) of ash from different sections of the boiler.

Table 1. Chemical composition of the BA samples. The values displayed are averages and RSD based on Day1, Day2 and Day3 samples. Data in bold are characterized by greater uncertainty, as one or more of the three samples was below the detection limit.

\begin{tabular}{|c|c|c|c|c|c|c|c|c|c|c|c|}
\hline & & \multicolumn{10}{|c|}{ Boiler section } \\
\hline & & 1 & 2 & 3 & 4 & 5 & 6 & 7 & 8 & 9 & 10 \\
\hline As & $\mathrm{mg} / \mathrm{kg}$ & $7 \mathrm{E}+02 \pm 33 \%$ & $1.6 \mathrm{E}+02 \pm 33 \%$ & $2 \mathrm{E}+02 \pm 25 \%$ & $\%$ & $\pm 31 \%$ & $\%$ & $\%$ & $02 \pm 29 \%$ & $26 \%$ & 3 \\
\hline $\mathrm{Ba}$ & $\mathrm{mg} / \mathrm{kg}$ & $1.0 \mathrm{E}+03 \pm 5.5 \%$ & $1.2 \mathrm{E}+03 \pm 9.9 \%$ & $1.3 \mathrm{E}+03 \pm 15 \%$ & $1.4 \mathrm{E}+03 \pm 12 \%$ & $1.3 \mathrm{E}+03 \pm 6.0 \%$ & $1.4 \mathrm{E}+03 \pm 17 \%$ & $1.3 \mathrm{E}+03 \pm 11 \%$ & $1.2 \mathrm{E}+03 \pm 14 \%$ & $1.3 \mathrm{E}+03 \pm 8.1 \%$ & $1.2 \mathrm{E}+03 \pm 8.1 \%$ \\
\hline $\mathrm{Be}$ & $\mathrm{mg} / \mathrm{kg}$ & $<0.025 \pm$ & $<0.025 \pm$ & $<0.025 \pm-$ & $<0.025 \pm$ & $<0.025 \pm$ & $<0.025 \pm$ & $<0.025 \pm$ & $<0.025 \pm$ & $<0.025 \pm$ & $<0.025 \pm$ \\
\hline $\mathrm{Cd}$ & $\mathrm{mg} / \mathrm{kg}$ & $3 \mathrm{E}+01 \pm 26 \%$ & $5.4 \mathrm{E}+01 \pm 19 \%$ & $5.1 \mathrm{E}+01 \pm 31 \%$ & $4.1 \mathrm{E}+01 \pm 21 \%$ & $4.8 \mathrm{E}+01 \pm 15 \%$ & $2.8 \mathrm{E}+01 \pm 12 \%$ & $6.0 \mathrm{E}+01 \pm 9.2 \%$ & $1.1 \mathrm{E}+02 \pm 6.7 \%$ & $8.2 \mathrm{E}+01 \pm 8.8 \%$ & $8.6 \mathrm{E}+01 \pm 18 \%$ \\
\hline Co & $\mathrm{mg} / \mathrm{kg}$ & $1 \pm$ & 4 & 4 & $5 \%$ & $\%$ & $4 \%$ & $\%$ & $\%$ & $5 \%$ & $\%$ \\
\hline $\mathrm{Cr}$ & $\mathrm{mg} / \mathrm{kg}$ & $7 \mathrm{E}+02 \pm$ & $1 \%$ & $\%$ & $5.0 \mathrm{E}$ & $0 \%$ & $2 \%$ & $20 \%$ & D\% & $\%$ & $35 \%$ \\
\hline $\mathrm{Cu}$ & $\mathrm{mg} / \mathrm{kg}$ & $6.4 \mathrm{E}+02 \pm 4.8 \%$ & $6.6 \mathrm{E}+02 \pm 7.0 \%$ & $6.4 \mathrm{E}+02 \pm 15 \%$ & $6.5 \mathrm{E}+02 \pm 12 \%$ & $6.5 \mathrm{E}+02 \pm 10 \%$ & $6.2 \mathrm{E}+02 \pm 11 \%$ & $7.2 \mathrm{E}+02 \pm 10 \%$ & $9.4 \mathrm{E}+02 \pm 7.8 \%$ & $8.2 \mathrm{E}+02 \pm 11 \%$ & $8.4 \mathrm{E}+02 \pm 13 \%$ \\
\hline $\mathrm{Hg}$ & $\mathrm{mg} / \mathrm{kg}$ & $<0.01 \quad \pm$ & 1.0E-02 \pm & $<0.01 \pm$ & $<0.01 \pm$ & $<0.01 \pm$ & 1.0E-02 \pm & $2.7 \mathrm{E}-02 \pm 43 \%$ & $1.2 \mathrm{E}-01 \pm 65 \%$ & $1.7 \mathrm{E}-01 \pm 39 \%$ & $3.4 \mathrm{E}-01 \pm 44 \%$ \\
\hline Mo & $\mathrm{mg} / \mathrm{kg}$ & $2 \mathrm{E}+01 \pm 23 \%$ & $5 \mathrm{E}+01 \pm 27 \%$ & $3.1 \mathrm{E}+01 \pm 16 \%$ & $3.5 \mathrm{E}+01 \pm 27 \%$ & $2.8 \mathrm{E}+01 \pm 11 \%$ & $3.5 \mathrm{E}+01 \pm 30 \%$ & $3.4 \mathrm{E}+01 \pm 34 \%$ & $3.2 \mathrm{E}+01 \pm 32 \%$ & $2.9 \mathrm{E}+01 \pm 34 \%$ & $2.7 \mathrm{E}+01 \pm 14 \%$ \\
\hline $\mathbf{N i}$ & $\mathrm{mg} / \mathrm{kg}$ & $8.5 \mathrm{E}+01 \pm 9.5 \%$ & $8.7 \mathrm{E}+01 \pm 5.3 \%$ & $9.7 \mathrm{E}+01 \pm 6.6 \%$ & $1.0 \mathrm{E}+02 \pm 9.0 \%$ & $8.6 \mathrm{E}+01 \pm 15 \%$ & $9.8 \mathrm{E}+01 \pm 19 \%$ & $1.1 \mathrm{E}+02 \pm 11 \%$ & $9.4 \mathrm{E}+01 \pm 3.8 \%$ & $9.8 \mathrm{E}+01 \pm 14 \%$ & $9.6 \mathrm{E}+01 \pm 8.8 \%$ \\
\hline $\mathrm{Pb}$ & $\mathrm{mg} / \mathrm{kg}$ & $2.5 \mathrm{E}+03 \pm 46 \%$ & $\pm 17 \%$ & $1.9 \mathrm{E}+03 \pm 29 \%$ & $3 \pm 15 \%$ & $19 \%$ & $2 \pm 19 \%$ & $15 \%$ & $.1 \%$ & $4 \%$ & $11 \%$ \\
\hline $\mathrm{S}$ & $\mathrm{mg} / \mathrm{kg}$ & $9.1 \mathrm{E}+04 \pm 19 \%$ & $7.1 \mathrm{E}+04 \pm 8.2 \%$ & $4.9 \mathrm{E}+04 \pm 19 \%$ & $4.2 \mathrm{E}+04 \pm 10 \%$ & $4.4 \mathrm{E}+04 \pm 19 \%$ & $3.1 \mathrm{E}+04 \pm 15 \%$ & $3.8 \mathrm{E}+04 \pm 10 \%$ & $4.3 \mathrm{E}+04 \pm 1.4 \%$ & $3.7 \mathrm{E}+04 \pm 6.3 \%$ & $3.6 \mathrm{E}+04 \pm 7.9 \%$ \\
\hline $\mathbf{S b}$ & $\mathrm{mg} / \mathrm{kg}$ & $5.2 \mathrm{E}+02 \pm 20 \%$ & $4.9 \mathrm{E}+02 \pm 12 \%$ & $3.6 \mathrm{E}+02 \pm 15 \%$ & $3.3 \mathrm{E}+02 \pm 15 \%$ & $3.6 \mathrm{E}+02 \pm 13 \%$ & $2.6 \mathrm{E}+02 \pm 16 \%$ & $3.6 \mathrm{E}+02 \pm 13 \%$ & $5.5 \mathrm{E}+02 \pm 8.0 \%$ & $4.8 \mathrm{E}+02 \pm 11 \%$ & $5.0 \mathrm{E}+02 \pm 12 \%$ \\
\hline Sn & $\mathrm{s} / \mathrm{kg}$ & $5 \mathrm{E}+02 \pm 2$ & $5.2 \mathrm{E}$ & $\%$ & $\%$ & $\%$ & $\%$ & $\%$ & $\%$ & $\%$ & $5.7 \mathrm{E}+$ \\
\hline $\mathrm{Sr}$ & $\mathrm{mg} / \mathrm{kg}$ & $-02 \pm 6.7 \%$ & $0 \%$ & $5 \%$ & $5 \%$ & $\%$ & $1 \%$ & $\%$ & $\%$ & $2 \%$ & $8 \%$ \\
\hline $\mathbf{v}$ & $\mathrm{mg} / \mathrm{kg}$ & $3.5 \mathrm{E}+01 \pm 5.4 \%$ & $3.9 \mathrm{E}+01 \pm 5.7 \%$ & $4.2 \mathrm{E}+01 \pm 11 \%$ & $4.7 \mathrm{E}+01 \pm 5.4 \%$ & $4.4 \mathrm{E}+01 \pm 1.0 \%$ & $4.9 \mathrm{E}+01 \pm 11 \%$ & $4.5 \mathrm{E}+01$ & $4.2 \mathrm{E}+01 \pm 9.0 \%$ & $4.4 \mathrm{E}+01 \pm 3.4 \%$ & $4.2 \mathrm{E}+01 \pm 1.4 \%$ \\
\hline $\mathrm{Zn}$ & $\mathrm{mg} / \mathrm{kg}$ & $1.3 \mathrm{E}+04 \pm 24 \%$ & $1.2 \mathrm{E}+04 \pm 21 \%$ & $9.9 \mathrm{E}+03 \pm 18 \%$ & $9.3 \mathrm{E}+03 \pm 22 \%$ & $9.5 \mathrm{E}+03 \pm 19 \%$ & $7.8 \mathrm{E}+03 \pm 23 \%$ & $1.1 \mathrm{E}+04 \pm 20 \%$ & $1.7 \mathrm{E}+04 \pm 12 \%$ & $1.4 \mathrm{E}+04 \pm 12 \%$ & $1.4 \mathrm{E}$ \\
\hline $\mathrm{Si}$ & $\mathrm{g} / \mathrm{kg}$ & $6.2 \mathrm{E}+01 \pm 10 \%$ & - & $\%$ & $1.0 \mathrm{E}+0$ & $9.4 \mathrm{E}+01 \pm$ & $0 \mathrm{E}+02 \pm 3.2 \%$ & $9.2 \mathrm{E}+01 \pm$ & $8.1 \mathrm{E}+01$ & $8.1 \mathrm{E}+$ & $7.4 \mathrm{E}+01 \pm 1.7 \%$ \\
\hline Al & $\mathrm{g} / \mathrm{kg}$ & $3.8 \mathrm{E}+01 \pm 13 \%$ & $4.6 \mathrm{E}+01 \pm 6.2 \%$ & $5.3 \mathrm{E}+01 \pm 8.6 \%$ & $5.8 \mathrm{E}+01 \pm 13 \%$ & $5.4 \mathrm{E}+01 \pm 17 \%$ & $6.1 \mathrm{E}+01 \pm 5.9 \%$ & $5.5 \mathrm{E}+01 \pm 11 \%$ & $4.8 \mathrm{E}+01 \pm 6.7 \%$ & $5.0 \mathrm{E}+01 \pm 9.8 \%$ & $4.7 \mathrm{E}+01 \pm 4.3 \%$ \\
\hline $\mathrm{Ca}$ & $\mathrm{g} / \mathrm{kg}$ & $2.1 \mathrm{E}+02 \pm 5.4 \%$ & $2.2 \mathrm{E}+02 \pm 1.7 \%$ & $2.3 \mathrm{E}+02 \pm 3.0 \%$ & $2.4 \mathrm{E}+02 \pm 2.7 \%$ & $2.2 \mathrm{E}+02 \pm 4.3 \%$ & $2.7 \mathrm{E}+02 \pm 2.7 \%$ & $2.5 \mathrm{E}+02 \pm 4.5 \%$ & $2.3 \mathrm{E}+02 \pm 3.2 \%$ & $2.4 \mathrm{E}+02 \pm 3.3 \%$ & $2.4 \mathrm{E}+02 \pm 2.5 \%$ \\
\hline $\mathrm{Fe}$ & $\mathrm{g} / \mathrm{kg}$ & $1.2 \mathrm{E}+01 \pm 4.0 \%$ & $1.4 \mathrm{E}+01 \pm 6.6 \%$ & $1.5 \mathrm{E}+01 \pm 15 \%$ & $1.7 \mathrm{E}+01 \pm 11 \%$ & $1.5 \mathrm{E}+01 \pm 6.6 \%$ & $1.7 \mathrm{E}+01 \pm 18 \%$ & $1.6 \mathrm{E}+01 \pm 15 \%$ & $1.5 \mathrm{E}+01 \pm 8.5 \%$ & $1.5 \mathrm{E}+01 \pm 9.3 \%$ & $2.4 \mathrm{E}+01 \pm 25 \%$ \\
\hline $\mathbf{K}$ & $\mathrm{g} / \mathrm{kg}$ & $5.2 \mathrm{E}+01 \pm 24 \%$ & $4.8 \mathrm{E}+01 \pm 9.4 \%$ & $3.5 \mathrm{E}+01 \pm 24 \%$ & $3.2 \mathrm{E}+01 \pm 12 \%$ & $3.7 \mathrm{E}+01 \pm 13 \%$ & $2.5 \mathrm{E}+01 \pm 5.9 \%$ & $3.5 \mathrm{E}+01 \pm 5.0 \%$ & $5.2 \mathrm{E}+01 \pm 2.9 \%$ & $4.3 \mathrm{E}+01 \pm 6.8 \%$ & $4.2 \mathrm{E}+01 \pm 8.0 \%$ \\
\hline $\mathrm{Mg}$ & $\mathrm{g} / \mathrm{kg}$ & $1.7 \mathrm{E}+01 \pm 7.7 \%$ & $1.8 \mathrm{E}+01 \pm 2.6 \%$ & $1.9 \mathrm{E}+01 \pm 4.0 \%$ & $1.9 \mathrm{E}+01 \pm 1.8 \%$ & $1.8 \mathrm{E}+01 \pm 2.2 \%$ & $2.1 \mathrm{E}+01 \pm 6.6 \%$ & $1.9 \mathrm{E}+01 \pm 2.5 \%$ & $1.9 \mathrm{E}+01 \pm 3.6 \%$ & $2.0 \mathrm{E}+01$ & $1.9 \mathrm{E}+01 \pm 2.3 \%$ \\
\hline $\mathrm{Mn}$ & $\mathrm{g} / \mathrm{kg}$ & $8.3 \mathrm{E}-01 \pm 5.0 \%$ & $9.0 \mathrm{E}-\mathrm{C}$ & $01 \pm 9.4 \%$ & $.8 \%$ & $1 \%$ & $5 \%$ & $0 \%$ & $1 \pm 8.1 \%$ & $\%$ & $\%$ \\
\hline $\mathrm{Na}$ & $\mathrm{g} / \mathrm{kg}$ & $4.2 \mathrm{E}+01 \pm 21 \%$ & $.0 \mathrm{E}+01 \pm 5.3 \%$ & $3.1 \mathrm{E}+01 \pm 18 \%$ & $3.0 \mathrm{E}+01 \pm 5.9 \%$ & $3.3 \mathrm{E}+01 \pm 7.1 \%$ & $2.6 \mathrm{E}+01 \pm 3.8 \%$ & $3.3 \mathrm{E}+01 \pm$ & $4.4 \mathrm{E}+01 \pm 2.4 \%$ & $3.7 \mathrm{E}+$ & $3.6 \mathrm{E}+01 \pm 4.8 \%$ \\
\hline $\mathbf{P}$ & $\mathrm{g} / \mathrm{kg}$ & $9.1 \mathrm{E}+00 \pm 12 \%$ & $9.9 \mathrm{E}+00 \pm 7.9 \%$ & $1.0 \mathrm{E}+01 \pm 8.3 \%$ & $1.1 \mathrm{E}+01 \pm 11 \%$ & $1.1 \mathrm{E}+01 \pm 13 \%$ & $1.2 \mathrm{E}+01 \pm 7.3 \%$ & $1.1 \mathrm{E}+01 \pm 11 \%$ & $1.1 \mathrm{E}+01 \pm 6.4 \%$ & $1.1 \mathrm{E}+01 \pm 12 \%$ & $1.1 \mathrm{E}+01 \pm 14 \%$ \\
\hline $\mathrm{Ti}$ & $\mathrm{g} / \mathrm{kg}$ & $9.6 \mathrm{E}+00 \pm 9.4 \%$ & $1.1 \mathrm{E}+01 \pm 1.8 \%$ & $1.2 \mathrm{E}+01 \pm 2.0 \%$ & $1.4 \mathrm{E}+01 \pm 2.7 \%$ & $1.3 \mathrm{E}+01 \pm 6.4 \%$ & $1.4 \mathrm{E}+01 \pm 2.5 \%$ & $1.3 \mathrm{E}+01 \pm 4.2 \%$ & $1.2 \mathrm{E}+01 \pm 2.1 \%$ & $1.2 \mathrm{E}+01 \pm 4.9 \%$ & $1.2 \mathrm{E}+01 \pm 4.1 \%$ \\
\hline
\end{tabular}


Contents of $\mathrm{Ca}, \mathrm{Mg}, \mathrm{Co}$ and $\mathrm{S}$ were higher than typical values reported for bottom ash and fly ash $[29,30]$, while $\mathrm{Cu}$ concentrations were lower. Contents of $\mathrm{Al}, \mathrm{Cr}, \mathrm{Pd}, \mathrm{Sr}$ and $\mathrm{V}$ were typical of bottom ash, as opposed to $\mathrm{Na}, \mathrm{K} \mathrm{Fe}, \mathrm{Mo}$ and $\mathrm{P}$ that approached typical fly ash concentrations. The content of other elements (i.e. $\mathrm{Cl}, \mathrm{As}, \mathrm{Ba}, \mathrm{Cd}, \mathrm{Ni}, \mathrm{Zn}$, and $\mathrm{Sb}$ ) was between typical values for bottom ash and fly ash. In addition, results in Table 1 agreed with previous levels detected in BA by other authors $[6,11]$. Results from the two sampling campaigns carried out for this study were consistent (see Table A2). The main differences were found for As, $\mathrm{Hg}$, Pb and $\mathrm{Zn}$. Particularly, As and $\mathrm{Hg}$ were found to be more than $50 \%$ higher during the first sampling campaign.

Enrichment trends were observed along the boiler, and some elements could be grouped based on similar behaviour. These trends relate to the mechanisms for deposits' formation mentioned in Section 3.1 and thereby to the boiler configuration. The significant enrichment of $\mathrm{Cl}, \mathrm{Na}, \mathrm{K}, \mathrm{Pb}, \mathrm{Sn}$, $\mathrm{Zn}$, and other metals (e.g. As and Sb) at the evaporator (Sec1) and superheater (Sec2), as well as in the economizer area, indicates the presence of condensation mechanisms. Salt species (e.g. $\mathrm{NaCl}$, $\mathrm{KCl}$ ) are likely to condense when in contact with cool surfaces, thereby enhancing condensation and deposition of other species - especially metals - and consequently increasing the catching surface area and altering the equilibrium conditions for trace and minor metals. The behaviour of metals is influenced especially by $\mathrm{Cl}$ and $\mathrm{S}$ chemistry within the boiler, as described in [31]. Even though most metals have thermodynamic stability as volatile species at the boiler temperatures, ash particles can capture these elements, which form stable solid phases with $\mathrm{Cl}$ and $\mathrm{SO}_{4}$. In this sense, XRD analyses performed by other authors [11] showed that $\mathrm{SiO}_{2}, \mathrm{CaSO}_{4}, \mathrm{KCl}, \mathrm{NaCl}$ and other solid solutions, including $\mathrm{SO}_{4}$, are the preponderant species in boiler ash. Constant concentrations along the boiler were found for $\mathrm{Co}, \mathrm{Cr}, \mathrm{Fe}, \mathrm{Mn}, \mathrm{Mo}, \mathrm{Ni}, \mathrm{P}, \mathrm{Sr}$ and $\mathrm{V}$, while elements such as $\mathrm{Al}, \mathrm{Ba}$, $\mathrm{Ca}, \mathrm{Mg}, \mathrm{Si}$ and $\mathrm{Sr}$ were slightly enriched in the central sections (particularly Sec6). Residues collected from Sec6 were characterized by a slightly lower content of metals such as As, $\mathrm{Cd}, \mathrm{Cu}$, $\mathrm{Pb}, \mathrm{Sb}, \mathrm{Sn}$, and $\mathrm{Zn}$. This supported the findings of the grain size distribution analysis: ash from Sec6 presented the lowest share of particles below $0.125 \mathrm{~mm}$, while trace and minor elements tend to enrich on the surface of the fine ash particles, where a larger specific surface is available for condensation. The concentrations of $\mathrm{Cu}, \mathrm{Cd}$, and particularly $\mathrm{Hg}$, increased towards the FGC system, as opposed to $\mathrm{S}$. Sulphate enrichment in the initial part of the energy recovery system was expected: sulphates can condensate at a high temperature, forming thermodynamically stable compounds such as $\mathrm{CaSO}_{4(\mathrm{~s})}$ [31]; $\mathrm{SO}_{2}$ sorption is enhanced in the first sections, where deposits are exposed to the flue gas for a longer time.

\subsection{2. $\mathrm{PCDD} / \mathrm{F}$}

The TEQ concentrations (Figure 4, top chart) displayed a profile over the different sections, with the highest TEQ concentrations found in the first and last sections, whereas the TEQ concentrations in Secs 6 and 7 were relatively low. A similar observation was made for the total concentrations of PCDF, where the highest concentrations were found in ash samples from Sec1, and the lowest in Sec6 (Figure 4, bottom chart). The PCDD, on the other hand, were the lowest in Sec1-Sec6, and did not differ notably between these sections, whereas the concentrations in Sec8 and Sec10 were the highest. This concentration profile with the lowest concentrations in the mid sections is most likely explained by boiler temperatures. Temperatures were, from a dioxin formation perspective, high over several sections. Flue gas temperatures were above $500^{\circ} \mathrm{C}$ in Sec1-Sec5 and dropped below $300^{\circ} \mathrm{C}$ (i.e. a lower temperature limit for PCDD/F formation) in Sec9. Thus, the results seemed to disagree with expected PCDD and PCDF levels, based on the established knowledge of PCDD/F formation. From these results, the entire investigated 
temperature range may be considered to be within the active window of PCDD/F formation. However, high levels of TEQ in high temperature sections can be caused by formation in the bottom part of the hoppers, where significant ash deposits and local temperature conditions can occur.

Correlating the TEQ concentrations for each section with the inorganic content of most influential elements $(\mathrm{Cu}, \mathrm{Cl}, \mathrm{Fe}$, and $\mathrm{S})$, the only element for which an observable correlation was found was sulphur. Sulphur is known as an inhibiting species in the chemistry of PCDD/F [32], and therefore the observed positive correlation is in contrast with previous investigations and cannot be explained based on the available data: the presence of sulphur in the flue gas is not known, neither is the gas-particle interactions and/or the exchange of sulphur.
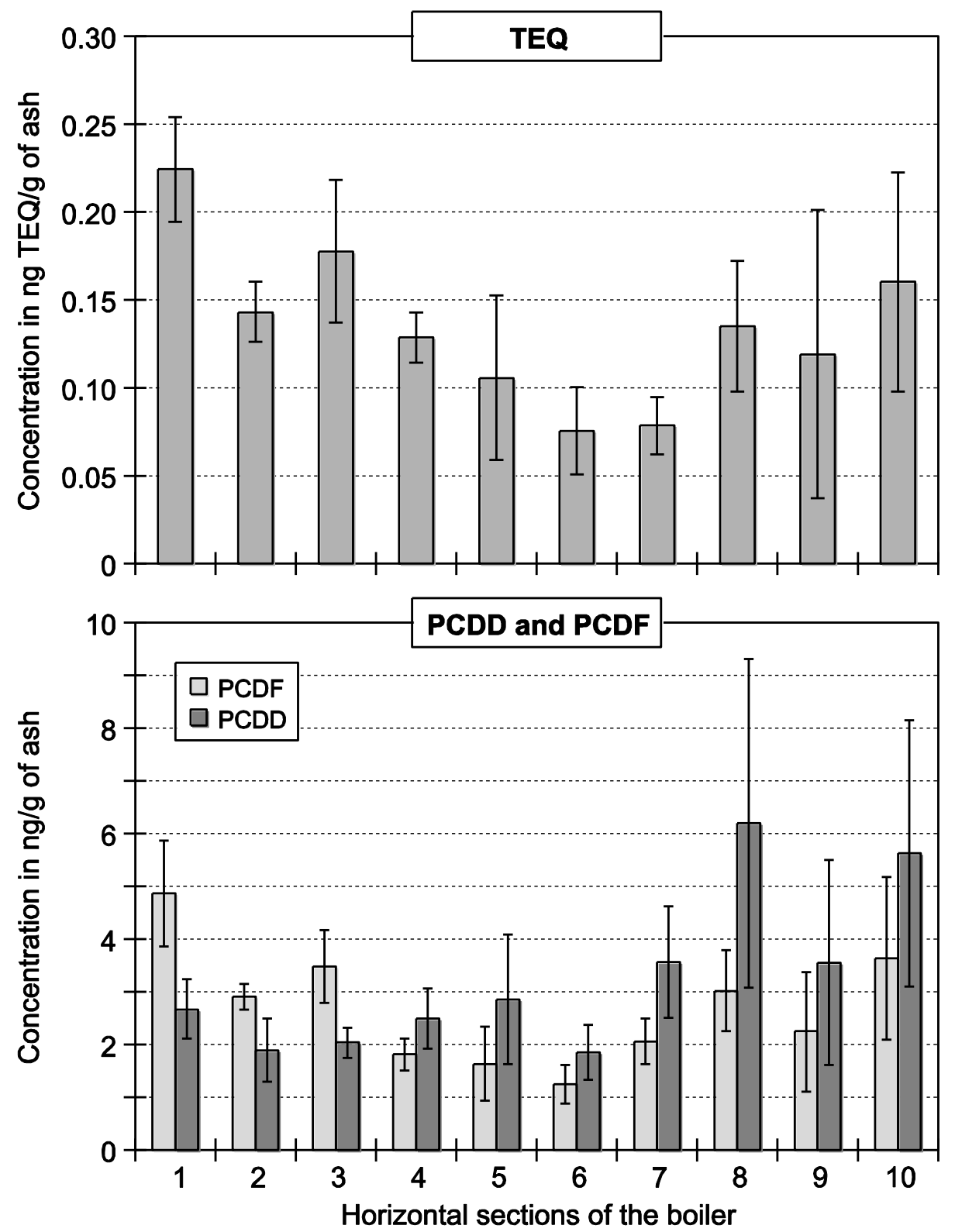

Figure 4. TEQ concentrations (top chart) and total concentrations of PCDF (white bars) and PCDD (grey bars) in the different sections (bottom chart). Concentrations are expressed in $\mathrm{ng} / \mathrm{g}$, and results are given as averages of triplicate samples. Error bars represent $\pm 1 \sigma$. 
When evaluating the influence of temperature in the different sections, it is important to note that the measured temperatures are recorded in passing flue gas, not in ash deposits. Since ash deposits may be said to constitute the main 'formation bed', or the formation surface, the temperature in the deposits may be of equal importance as in the flue gases. Since the temperatures in the ash deposits in the hoppers or in wall deposits are not known, their effect in the formation of PCDDs and PCDFs is difficult to assess. On the other hand, what can be concluded is that differences in ash deposition time (i.e. time between rapping events) and the average particle deposition rate in the hoppers may result in substantial differences in deposits available as PCDD and PCDF formation sites. In effect, the results from the first sampling campaign were significantly different (see Fig.A3 and Fig.A4 in Appendix. A): the trend in TEQ concentrations within the boiler was found to increase from Secs1 to 10, and to be well correlated with the temperature trend, as well as with the content of $\mathrm{Cl}$ and $\mathrm{Cu}$. However, as no major events were reported in the plant operations during the second sampling campaign, we can conclude that different trends and concentrations of PCDD/F can occur within the boiler at regular operating conditions.

\subsection{Leaching behaviour}

Table 2 shows the release of inorganic elements, according to the compliance leaching test EN 12457-1. The $\mathrm{pH}$ of the eluates did not vary significantly between sections, with values ranging between 12.4 and 12.8. This is an indication of the irritant and corrosive nature of the BA and, according to the revised Waste Framework Directive (2008/98/EC) [4], the material exceeded threshold limits for hazard categories $\mathrm{H} 4$ and $\mathrm{H} 8$ (irritant and corrosive), having a $\mathrm{pH}>11.5$ [33].

The largest release was seen for availability controlled elements such as $\mathrm{Cl}, \mathrm{K}$ and $\mathrm{Na}$, whose release follows the same enrichment trend seen for the compositional results (Table 1). Residues from all sections exceeded limits for disposal in landfill for hazardous waste [25], as the release of $\mathrm{Cl}$ was above $17,000 \mathrm{mg} / \mathrm{kg}$. The release of $\mathrm{Pb}$ also exceeded the limit of $25 \mathrm{mg} / \mathrm{kg}$ for all sections but Sec6. The release of $\mathrm{Cr}$ was slightly below the same limit of $25 \mathrm{mg} / \mathrm{kg}$. Other critical elements were Se (all sections) and S (for Sec1 and Sec5), which, together with $\mathrm{Na}$ and $\mathrm{Zn}$, were found to exceed Danish limits for residue utilization in construction works [24]. The same elements were found to be critical based on the results from the first sampling campaign (see Table A.3).

The samples were investigated further on the basis of the $\mathrm{pH}$ static leaching test (Figure 5 and Fig.A6), where the acid neutralization capacity (ANC) of the material was also estimated. The $\mathrm{ANC}_{\mathrm{pH} 7}$ and $\mathrm{ANC}_{\mathrm{pH} 4}$ ranged between 1.5-4 meq/g and 4.5-10 meq/g, respectively, with maximum values seen for the central sections (particularly Sec6) and minimum values registered for Sec1 and Sec2. Residues from different sections showed similar leaching behaviour, with a few exceptions. $\mathrm{Ca}$ and $\mathrm{Ba}$ which did not show significant differences in the total content, in the release the two elements were significantly different between sections (see Fig.A7). The release of these two elements increased from Sec1 to 10, indicating an evolution in the material geochemistry along the boiler, however few other elements presented statistically significant differences in the release. $\mathrm{S}$ release presented also important differences: Sec1 presented a significant release of $\mathrm{S}$ at $\mathrm{pH} 12$ compared to other sections and $\mathrm{pH}$ conditions. The increasing release of $\mathrm{S}$ towards alkaline condition is typical of sulphate anydrite $\left(\mathrm{CaSO}_{4}\right)$. This is in agreement with the experimental findings of previous authors (e.g. [34]) which found $\mathrm{CaSO}_{4}$ as predominant mineral in the entrance area of a MSWI boiler. According to the same authors, at lower temperatures sulphate phases with $\mathrm{Na}$ and $\mathrm{K}$ are predominant, thus explaining the flattening of 
the $\mathrm{S}$ release curve as function of $\mathrm{pH}$. As typical for availability controlled elements, the release of $\mathrm{Na}$ and $\mathrm{Cl}$ was $\mathrm{pH}$ independent, and the differences between sections were correlated with differences in the total content. The remaining critical elements ( $\mathrm{Se}, \mathrm{Cr}, \mathrm{Zn}, \mathrm{Pb}$ ) did not show differences in the release at any $\mathrm{pH}$ between sections, even though these are typical solubility controlled elements: thus changes in material geochemistry affect the leaching behaviour. The release of $\mathrm{Cr}, \mathrm{Pb}$, Se and $\mathrm{Zn}$ was influenced by $\mathrm{pH}$ conditions following typical release curves, as found for other incineration residues (e.g. [7, 35, 36, 37, 38, 39]). Similar results were obtained during the first sampling campaign (results reported in Fig. A5).

Table 2. Release $(\mathrm{mg} / \mathrm{kg}$ ) of inorganic elements (EN 12457-1) from the BA samples. The values displayed are averages and RSD based on Day1, Day2 and Day3 samples. Data in bold are characterized by greater uncertainty, as one or more of the three samples was below the detection limit.

\begin{tabular}{|c|c|c|c|c|c|c|c|c|c|c|c|}
\hline \multicolumn{12}{|c|}{ tion } \\
\hline & & 1 & 2 & 3 & 4 & 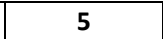 & 6 & 7 & 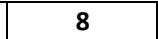 & r & D \\
\hline $\mathrm{Al}$ & $\mathrm{s} / \mathrm{k}$ & $-01 \pm-$ & $4 \pm-$ & $.14 \pm \quad-$ & $8 \mathrm{E}- \pm-$ & $14 \pm-$ & $E-01 \pm$ & $.14 \pm$ & $.14 \pm-$ & $\%$ & is \\
\hline As & $\mathrm{g} / \mathrm{k}$ & E-01士 - & $.028 \pm-$ & $<0.028 \pm \quad-$ & $1.5 \mathrm{E}- \pm \quad-$ & $<0.028 \pm-$ & $9.46 \mathrm{E}- \pm \quad-$ & $<0.028 \pm \quad-$ & $1.1 \mathrm{E}- \pm-$ & $3 \mathrm{E}-01 \pm \quad-$ & $2 \pm \quad-$ \\
\hline $\mathrm{Ba}$ & $\mathrm{g} / \mathrm{k}$ & $E-01 \pm 103$ & $5.3 \mathrm{E}- \pm 79 \%$ & $5.6 \mathrm{E}- \pm 49 \%$ & $5.6 \mathrm{E}- \pm 31 \%$ & $3.3 \mathrm{E}-01 \pm 50 \%$ & $1.5 \mathrm{E}+00 \pm 12 \%$ & $8.7 \mathrm{E}- \pm 1.5 \%$ & $1.1 \mathrm{E}+0 \pm 23 \%$ & 6 & 2.3 \\
\hline 0 & $\mathrm{~g} / \mathrm{k}$ & \pm- & $7.2 \mathrm{E}- \pm 55 \%$ & $7.6 \mathrm{E}- \pm 12 \%$ & $8.0 \mathrm{E}- \pm 7.9$ & $2 \pm 39 \%$ & 7 & $6.6 \mathrm{E}- \pm 23 \%$ & $\%$ & & 5 \\
\hline a & $\mathrm{g} / \mathrm{k}$ & $1.8 \mathrm{E}+03 \pm 29 \%$ & $1 \mathrm{E}+0 \pm 31 \%$ & $2.7 \mathrm{E}+0 \pm 28 \%$ & $2.2 \mathrm{E}+0 \pm 9.3$ & $1.4 \mathrm{E}+03 \pm 29 \%$ & $3 \pm 13 \%$ & $3.1 \mathrm{E}+0 \pm 7.4 \%$ & $3.2 \mathrm{E}+0 \pm 24 \%$ & $3 \%$ & \\
\hline $\mathrm{Cd}$ & $\mathrm{mg} / \mathrm{k}$ & $5 E-03 \pm 16 \%$ & $1.2 \mathrm{E}- \pm 12 \%$ & 7.7E- \pm- & $8.3 \mathrm{E}- \pm \quad-$ & $7 \mathrm{E}-02 \pm 46 \%$ & $3 \pm$ & $6.3 \mathrm{E}- \pm \quad-$ & $.1 \mathrm{E}- \pm 13 \%$ & $2 \pm \quad-$ & $13 \%$ \\
\hline Co & $\mathrm{mg} / \mathrm{k}$ & $<0.014 \pm-$ & $<0.014 \pm-$ & $<0.014 \pm \quad-$ & $<0.014 \pm \quad-$ & $<0.014 \pm-$ & $14 \pm-$ & $<0.014 \pm \quad-$ & $0.014 \pm-$ & $<0.014 \pm \quad-$ & $<0.014 \pm \quad-$ \\
\hline $\mathrm{Cr}$ & $\mathrm{g} / \mathrm{k}$ & $2.1 \mathrm{E}+01 \pm 22 \%$ & $1.8 \mathrm{E}+0 \pm 18 \%$ & $1.7 \mathrm{E}+0 \pm 21 \%$ & $1.7 \mathrm{E}+0 \pm 23 \%$ & $2.1 \mathrm{E}+01 \pm 23 \%$ & $1 \pm 12 \%$ & $2.0 \mathrm{E}+0 \pm 21 \%$ & $1.5 \mathrm{E}+0 \pm 38 \%$ & $1.6 \mathrm{E}+01 \pm 17 \%$ & $1.2 \mathrm{E}+01 \pm 23 \%$ \\
\hline $\mathrm{Cu}$ & $\mathrm{g} / \mathrm{k}$ & $2 \pm \quad-$ & $5.0 \mathrm{E}- \pm-$ & $7.6 \mathrm{E}- \pm-$ & $<0.014 \pm-$ & $.1 \mathrm{E}-01 \pm 56 \%$ & $4 \pm-$ & $5.9 \mathrm{E}- \pm \quad-$ & 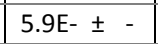 & $6.0 \mathrm{E}-02 \pm-$ & $2 \pm$ \\
\hline $\mathrm{Fe}$ & $\mathrm{mg} / \mathrm{k}$ & $4 \pm-$ & $4 \pm-$ & $14 \pm-$ & $4 \pm-$ & $4 \pm-$ & \pm- & $44 \pm \quad-$ & $<0.14 \pm-$ & + \pm & - \\
\hline $\mathrm{K}$ & $\mathrm{g} / \mathrm{k}$ & $4.0 E+04 \pm 8.6 \%$ & $3.6 \mathrm{E}+0 \pm 2.3$ & $2.6 \mathrm{E}+0 \pm 16 \%$ & $2.7 E+0 \pm 14 \%$ & $3.5 E+04 \pm 4.5$ & $4 \pm 7.1$ & $2.9 \mathrm{E}+0 \pm 4.7 \%$ & $4.3 E+0 \pm 1.7$ & $3.6 E+04 \pm 5.4$ & S.OLTU4I II\% \\
\hline $\mathrm{M}$ & $\mathrm{g} / \mathrm{k}$ & $4.2 \mathrm{E}-01 \pm \quad-$ & $1.5 \mathrm{E}- \pm-$ & $8.8 \mathrm{E}- \pm-$ & $9.5 \mathrm{E}- \pm-$ & $1 \pm-$ & & $<0.028 \pm \quad-$ & $<0.028 \pm \quad-$ & $<0.028 \pm-$ & $<0.028 \pm$ \\
\hline$M$ & $\mathrm{~g} / \mathrm{k}$ & $5.3 \mathrm{E}-02 \pm 30 \%$ & $3.6 \mathrm{E}- \pm 22 \%$ & $2.5 \mathrm{E}- \pm 32 \%$ & $2.4 \mathrm{E}- \pm 22 \%$ & $\pm 31 \%$ & $2 \pm 33 \%$ & $2.1 \mathrm{E}- \pm 49 \%$ & $4.3 \mathrm{E}- \pm 13 \%$ & $2 \pm 29 \%$ & 2.8 \\
\hline$M$ & $\mathrm{~g} / \mathrm{k}$ & $0 \pm 39 \%$ & $3.3 E+0 \pm 47 \%$ & $2.1 \mathrm{E}+0 \pm 62 \%$ & $1.8 \mathrm{E}+0 \pm 67 \%$ & $3 \%$ & $\pm 94 \%$ & $1.7 \mathrm{E}+0 \pm 62 \%$ & $3.9 E+0 \pm 20 \%$ & $2.3 \mathrm{E}$ & [2.02 \\
\hline $\mathrm{Ja}$ & $3 / k$ & $3+04 \pm 15 \%$ & $3.1 \mathrm{E}+0 \pm 3.2$ & $2.3 \mathrm{E}+0 \pm 18 \%$ & $2.3 \mathrm{E}+0 \pm 12 \%$ & 4.9 & $04 \pm 4.6$ & $2.5 \mathrm{E}+0 \pm 0.28$ & $3.7 \mathrm{E}+0 \pm 1.8$ & 0 & $3.0 \mathrm{E}+04 \pm 10 \%$ \\
\hline $\mathrm{Ni}$ & $\mathrm{g} / \mathrm{k}$ & $\pm \quad-$ & $7 \pm-$ & $\pm \quad-$ & \pm & \pm- & \pm- & I & I - & \pm- & 4. \\
\hline $\mathrm{P}$ & $\mathrm{g} / \mathrm{k}$ & $5.8-01 \pm 28 \%$ & $5.1 \mathrm{E}- \pm 40 \%$ & $6.7 \mathrm{E}- \pm 6.4$ & $7.6 \mathrm{E}- \pm 26 \%$ & 6.3 & \pm 6.0 & $5.8 \mathrm{E}- \pm 31 \%$ & $.8 \mathrm{E}- \pm 31 \%$ & 4.7 & $8 \%$ \\
\hline $\mathrm{Pb}$ & $\mathrm{mg} / \mathrm{k}$ & $3.7 \mathrm{E}+01 \pm 49 \%$ & $4.7 \mathrm{E}+0 \pm 75 \%$ & $5.0 \mathrm{E}+0 \pm 35 \%$ & $3.8 \mathrm{E}+0 \pm 23 \%$ & $8.6 \mathrm{E}+01 \pm 15 \%$ & $1 \pm 29 \%$ & $3.7 \mathrm{E}+0 \pm 39 \%$ & $6.3 \mathrm{E}+0 \pm 21 \%$ & $5.4 \mathrm{E}$ & $\%$ \\
\hline $\mathrm{S}$ & $\mathrm{g} / \mathrm{k}$ & $1.9 \mathrm{E}+04 \pm 46 \%$ & $9 . E+03 \pm 23 \%$ & $6.1 \mathrm{E}+0 \pm 37 \%$ & $7.2 \mathrm{E}+0 \pm 17 \%$ & $1.6 \mathrm{E}+04 \pm 17 \%$ & $03 \pm 11 \%$ & $4.9 \mathrm{E}+0 \pm 8.0 \%$ & $6.9 \mathrm{E}+0 \pm 25 \%$ & $3.0 \mathrm{E}$ & $2.2 \mathrm{E}$ \\
\hline $\mathrm{Sb}$ & $\mathrm{mg} / \mathrm{k}$ & $<0.28 \pm-$ & $<0.28 \pm-$ & $<0.28 \pm \quad-$ & $<0.28 \pm-$ & $<0.28 \pm-$ & $8 \pm-$ & $<0.28 \pm \quad-$ & $<0.28 \pm-$ & $<0.2$ & $3 \pm$ \\
\hline $\mathrm{Se}$ & $\mathrm{mg} / \mathrm{k}$ & $1.6 \mathrm{E}+00 \pm 10 \%$ & $1.1 \mathrm{E}+0 \pm 5.9$ & $1.1 \mathrm{E}+0 \pm 16 \%$ & $1.1 \mathrm{E}+0 \pm 13 \%$ & $1.1 \mathrm{E}+00 \pm 57 \%$ & $01 \pm 47 \%$ & $6.4 \mathrm{E}- \pm 59 \%$ & $7.4 \mathrm{E}- \pm 11 \%$ & 5.9 & $1 \pm 7.6 \%$ \\
\hline $\mathrm{Si}$ & $\mathrm{g} / \mathrm{k}$ & $2.2 \mathrm{E}+00 \pm 31 \%$ & $1.2+00 \pm 9.0$ & $9.8 \mathrm{E}- \pm 8 \%$ & $1.2 \mathrm{E}+0 \pm 14 \%$ & $1.4 \mathrm{E}+00 \pm 16 \%$ & $00 \pm 34 \%$ & $1.1 \mathrm{E}+0 \pm 25 \%$ & $1.5 E+0 \pm 29 \%$ & $9.1 \mathrm{E}-01 \pm 7.8$ & 7.7E-01 $\pm 4.0 \%$ \\
\hline Sn & $\mathrm{mg} / \mathrm{k}$ & $7.60 \mathrm{E}- \pm \quad-$ & $<0.14 \pm-$ & $<0.14 \pm-$ & $<0.14 \pm-$ & $4.84 \mathrm{E}- \pm \quad-$ & \pm & $<0.14 \pm \quad-$ & $<0.14 \pm-$ & $5.18 \mathrm{E}- \pm \quad-$ & $5.75 \mathrm{E}- \pm$ \\
\hline $\mathrm{Sr}$ & $\mathrm{mg} / \mathrm{k}$ & $1.4 \mathrm{E}+01 \pm 61 \%$ & $2.1 \mathrm{E}+0 \pm 27 \%$ & $2.8 \mathrm{E}+0 \pm 26 \%$ & $2.6 \mathrm{E}+0 \pm 10 \%$ & $1.5 \mathrm{E}+01 \pm 14 \%$ & $1 \pm 2.2$ & $3.5 \mathrm{E}+0 \pm 1.6 \%$ & $3.4 \mathrm{E}+0 \pm 15 \%$ & $4.8 \mathrm{E}+01 \pm 5.1$ & $5.5 \mathrm{E}+01 \pm 5.8 \%$ \\
\hline $\mathrm{Ti}$ & $\mathrm{mg} / \mathrm{k}$ & $<0.028 \pm-$ & $<0.028 \pm-$ & $<0.028 \pm-$ & $<0.028 \pm \quad-$ & $<0.028 \pm-$ & $8 \pm-$ & $<0.028 \pm \quad-$ & $<0.028 \pm \quad-$ & $<0.028 \pm-$ & $<0.028 \pm \quad-$ \\
\hline $\mathrm{V}$ & $\mathrm{mg} / \mathrm{k}$ & $2.3 \mathrm{E}-02 \pm \quad-$ & 3.1E- \pm- & $<0.005 \pm \quad-$ & $<0.005 \pm \quad-$ & $<0.0059 \pm \quad-$ & $3.1 \mathrm{E}-02 \pm$ & $<0.005 \pm \quad-$ & $<0.005 \pm-$ & $2.18 \mathrm{E}- \pm$ & $2.7 \mathrm{E}-02 \pm 22$ \\
\hline $\mathrm{Zn}$ & $\mathrm{mg} / \mathrm{k}$ & $1.5 \mathrm{E}+01 \pm 25 \%$ & $1.4 \mathrm{E}+0 \pm 18 \%$ & $1.1 \mathrm{E}+0 \pm 18 \%$ & $1.2 \mathrm{E}+0 \pm 5.3$ & $1.8 \mathrm{E}+01 \pm 4.9$ & $6.6 \mathrm{E}+00 \pm 13 \%$ & $8.3 \mathrm{E}+0 \pm 11 \%$ & $9.2 \mathrm{E}+0 \pm 5.1$ & $7.9 \mathrm{E}+00 \pm 7.9$ & $9.3 \mathrm{E}+00 \pm 3.8 \%$ \\
\hline $\mathrm{Cl}$ & $\mathrm{mg} / \mathrm{k}$ & $4.9 \mathrm{E}+04 \pm 11 \%$ & $5.2 \mathrm{E}+0 \pm 10 \%$ & $4.1 \mathrm{E}+0 \pm 8.3$ & $3.8 \mathrm{E}+0 \pm 16 \%$ & $3.5 E+04 \pm 3.9$ & $5.0 \mathrm{E}+04 \pm 7.8$ & $5.6 \mathrm{E}+0 \pm 2.9 \%$ & $7.4 \mathrm{E}+0 \pm 4.4$ & $6.8 \mathrm{E}+04 \pm 10 \%$ & $6.0 \mathrm{E}+04 \pm 18 \%$ \\
\hline $\mathrm{pH}$ & & $12.60 \pm 2.5 \%$ & $12.73 \pm 1.0$ & $12.72 \pm 1.4$ & $12.75 \pm 1.1$ & $12.81 \pm 1.3$ & $12.52 \pm 1.3$ & $12.62 \pm 0.77$ & $12.60 \pm 1.2$ & $12.50 \pm 1.3$ & $1239+170$ \\
\hline
\end{tabular}




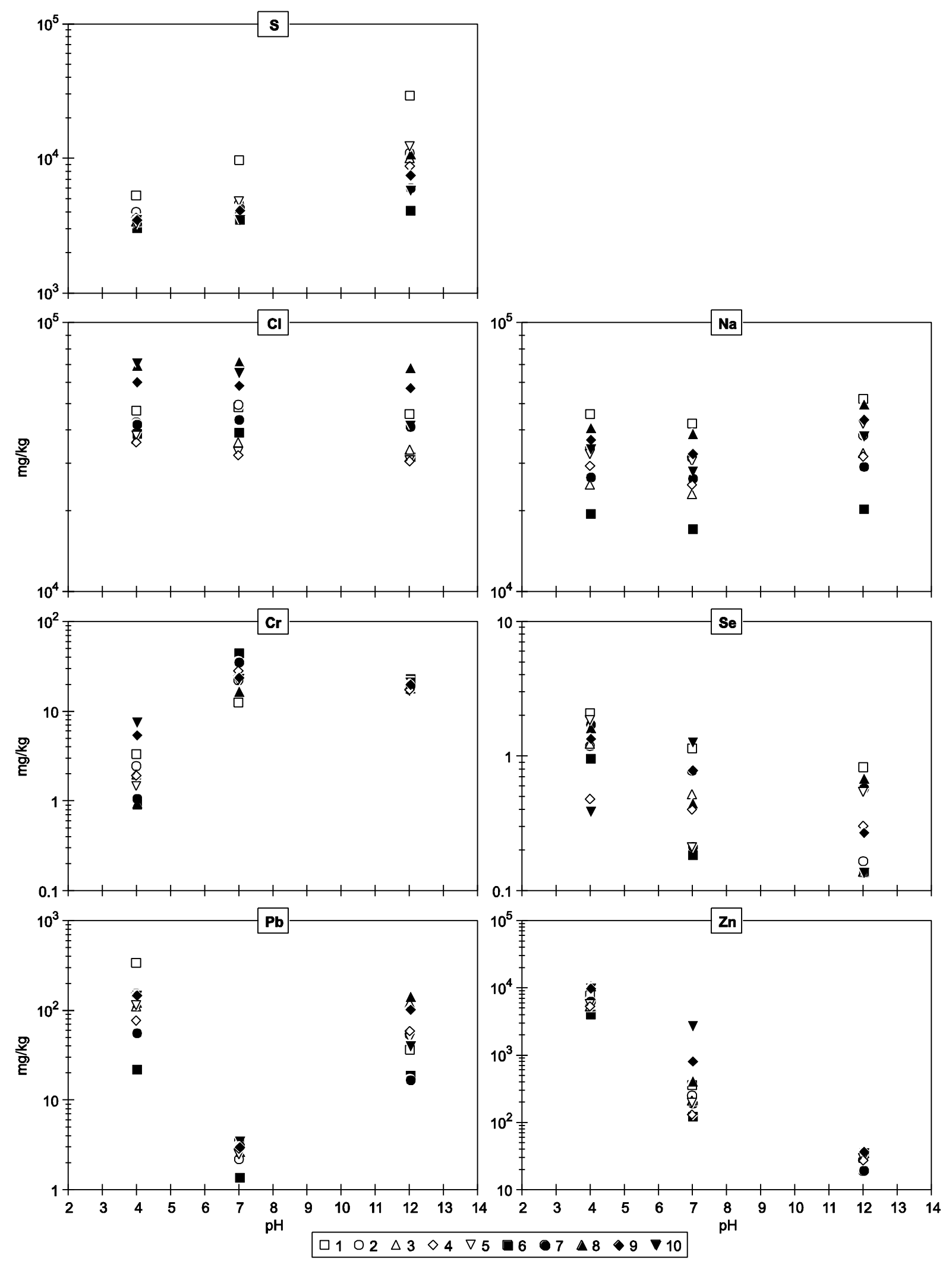

Figure 5. Release $(\mathrm{mg} / \mathrm{kg})$ of critical elements at pH 4, 7 and 12 (EN 14997). The values displayed are averages of the triplicate samples. y-axis is on log-scale and different scales are used for individual elements. For sake of clarity, errors bars are reported in the Fig. A,6. 


\subsection{Implications for BA management}

Both BA and bottom ash are included in the European Waste Catalogue as mirror entry hazardous waste, meaning that the hazardousness or non-hazardousness of the material is not absolute, but depends on the presence of dangerous substances in concentrations exceeding given thresholds $[4,33,40]$. Moreover, the hazardousness is not related directly to the total concentration of the element, but to the form (compound/substance) in which the element is present in the waste material. The concentrations of hazardous compounds, such as PCDDs and PCDFs, were found below critical levels along the boiler. The maximum observed TEQ concentration was lower than $0.4 \mathrm{ng} / \mathrm{g}$, thus well below the limit of $15 \mathrm{ng} / \mathrm{g}$ imposed by European regulation on persistent organic pollutants No. 850/2004 [41, 42]. However the total content of some elements (especially $\mathrm{Na}, \mathrm{K}, \mathrm{Cl}$ and S) approached typical levels detected for hazardous residues from the FGC system. In particular, the significant content of species containing alkali, alkali-earth metals and $\mathrm{Cl}$, conferred reactivity to the material, and the related high $\mathrm{pH}$ confined it within the hazard categories of irritant and corrosive. Results presented in Figure 5 showed no significant differences in the response to variations in $\mathrm{pH}$ conditions. This could indicate that the identified critical elements were present in similar speciation along the boiler. Thus the hazardousness is likely to be consistent between residues collected at different points. Thus, on the basis of this study, separate management for BA flows originating from individual sections of the boiler is not a realistic option.

\section{Conclusions}

With the aim of optimizing WtE ash management, a detailed characterization of the residues produced in the convective part of the energy recovery section of a WtE plant was performed. Residues were collected separately for the ten horizontal sections of the boiler, each section corresponding to a discharging hopper. The ash production was estimated to be between 2 and 3 $\mathrm{kg}$ per $\mathrm{t}$ of waste, with the largest amount being produced at the beginning of the economizer. The results of the chemical and physical characterization, as well of the leaching tests, did not show significant differences between the residues produced at the different sections. Condensation mechanisms appeared to control the elements enrichment trends along the boiler. PCDD/F were well below critical levels. However, PCDD/F formation was observed in boiler sections in which the temperature of the flue gas was above $500^{\circ} \mathrm{C}$, thus suggesting that PCDD/F concentrations in the residues are correlated to factors other than flue gas temperature (e.g. temperature of the ash deposits in the boiler). Hence, further investigations are required to fully document PCDD/F formation and behaviour in the boiler. Danish limits for residue utilization in construction works, as well as limits for disposal in landfill for hazardous waste, were exceeded by all samples because of the high release of $\mathrm{Cl}, \mathrm{Cr}, \mathrm{Pb}, \mathrm{Zn}, \mathrm{Na}, \mathrm{S}$ and $\mathrm{Se}$. The ten ash types exhibited the same hazardous properties because of the high reactivity demonstrated by the high $\mathrm{pH}$ values, and the release of elements such as $\mathrm{Cl}, \mathrm{K}$ and $\mathrm{Na}$. In addition, the measured release of critical elements at different $\mathrm{pH}$ conditions indicated the consistency of metals speciation along the boiler, even though variations in $\mathrm{S}, \mathrm{Ca}$, and $\mathrm{Ba}$ leaching suggests that geochemistry of the samples evolves along the boiler. Consequently, on the basis of this study, the selection of separate BA streams in the convective part of the boiler, to increase environmental and economic benefits, is not justified. 


\section{Acknowledgement}

Energinet.dk is acknowledged for funding the project PSO-10627. The Authors would like to thank Rambøll Energy and AffaldPlus, who were partners in the project. The Authors would also like to thank Sinh Hy Nguyen and Susanne Kruse for their assistance in the laboratory work, and Line KaiSørensen Brogaard, Kostyantyn Pivnenko and Roberto Turconi for their help during the sampling campaign.

Appendix A. Supplementary data

Supplementary data associated with this article can be found, in the online version, at XXXX. 


\section{References}

[1] DEPA, Affaldsstatistik 2009. Orientering fra Miljøstyrelsen Nr. 4, 2011. In Danish. Danish Environmental Protection Agency. 2011.

[2] ISWA, Working Group on Energy Recovery, Waste-to-Energy State-of-the-Art-Report, 6th edition, Rambøll Denmark. 2012.

[3] Danish Energy Agency, 2013, retrieved from http://www.ens.dk on 2/12/2013.

[4] European Commission, Directive 2008/98/EC of the European parliament and the council on waste and repealing certain Directive, 2008.

[5] O. Hjelmar, Disposal strategies for municipal solid waste incineration residues, J. Hazard. Mater. 47 (1996) 345-368.

[6] A. Phongphiphat, C. Ryu, K.N. Finney, V.N. Sharifi, J. Swithenbank, Ash deposit characterization in a large-scale municipal waste-to-energy incineration plant, J. Hazard. Mater. 186 (2011) 218-226.

[7] A.J. Chandler, T.T. Eighmy, J. Hartlen, O. Hjelmar, D.S. Kosson, S. Sawell, H. van der Sloot, J. Vehlow, Municipal Solid Waste Incinerator Residues, Elsevier, 1997.

[8] G. Mariani, E. Benfenati, R. Fanelli, Concentrations of PCDD and PCDF in different points of a modern refuse incinerator, Chemosphere. 21 (1990) 507-517.

[9] U. Düwel, A. Nottrodt, K. Ballschmiter, Simultaneous sampling of PCDD/PCDF inside the combustion chamber and on four boiler levels of a waste incineration plant, Chemosphere. 20 (1990) 1839-1846.

[10] P. Wunsch, S. Leichsenring, K.W. Schramm, A. Kettrup, Temperature dependence of PCDD/Fformation in boiler ash, Chemosphere. 29 (1994) 1235-1243.

[11] Y. Yang, Y. Xiao, J.H.L. Voncken, N. Wilson, Thermal treatment and vitrification of boiler ash from a municipal solid waste incinerator, J. Hazard. Mater. 154 (2008) 871-879.

[12] N. Saikia, G. Cornelis, G. Mertens, J. Elsen, K. Van Balen, T. Van Gerven, C. Vandecasteele, Assessment of Pb-slag, MSWI bottom ash and boiler and fly ash for using as a fine aggregate in cement mortar, J. Hazard. Mater. 154 (2008) 766-777.

[13] A. De Boom, M. Degrez, Belgian MSWI fly ashes and APC residues: A characterisation study, Waste Manage. 32 (2012) 1163-1170.

[14] A. De Boom, M. Degrez, P. Hubaux, C. Lucion, MSWI boiler fly ashes: Magnetic separation for material recovery, Waste Manage. 31 (2011) 1505-1513.

[15] L. Petersen, C.K. Dahl, K.H. Esbensen, Representative mass reduction in sampling: A critical survey of techniques and hardware, Chemometr. Intell. Lab. 74 (2004) 95-114.

[16] ASTM Standard C136-06. Standard Test Method for Sieve Analysis of Fine and Coarse Aggregates. Philadelphia, PA, 2005.

[17] DS/EN 13656:2003, Characterization of waste: Microwave-assisted digestion with hydrofluoric $(\mathrm{HF})$, nitric $(\mathrm{HNO})$ and hydrochloric $(\mathrm{HCl})$ acid mixture for subsequent determination of elements, 2003. 
[18] DS 259:2003 Determination of metals in water, sludge and sediments - General guidelines for determination by atomic absorption spectrophotometry in flame, 2003.

[19] DS/EN 15682:2001 Water quality - Determination of chloride by flow analysis (CFA and FIA) and photometric or potentiometric detection, 2001.

[20] P. Liljelind, G. Söderström, B. Hedman, S. Karlsson, L. Lundin, S. Marklund, Method for multiresidue determination of halogenated aromatics and PAHs in combustion-related samples, Environ. Sci. and Technol. 37 (2003) 3680-3686.

[21] J.J. Ryan, H.B.S. Conacher, L.G. Panopio, B.P.Y. Lau, J.A. Hardy, Y. Masuda, Gas chromatographic separations of all 136 tetra- to octa-polychlorinated dibenzo-p-dioxins and polychlorinated dibenzofurans on nine different stationary phases, J. Chromatogr. 541 (1991) 131-183.

[22] M. Van den Berg, L.S. Birnbaum, M. Denison, M. De Vito, W. Farland, M. Feeley, H. Fiedler, H. Hakansson, A. Hanberg, L. Haws, M. Rose, S. Safe, D. Schrenk, C. Tohyama, A. Tritscher, J. Tuomisto, M. Tysklind, N. Walker, R.E. Peterson, The 2005 World Health Organization reevaluation of human and mammalian toxic equivalency factors for dioxins and dioxin-like compounds, Toxicological Sciences. 93 (2006) 223-241.

[23] EN 12457-1, Characterization of waste - Leaching - Compliance test for leaching of granular waste materials and sludges - Part 1: One stage batch test at a liquid to solid ratio of $2 \mathrm{l} / \mathrm{kg}$ for materials with high solid content and with particle size below $4 \mathrm{~mm}$ (without or with size reduction), 2002.

[24] BEK nr. 1662 af 21/12/2010. Danish Statutory Order on the use of residues and soil for construction and the use of sorted, uncontaminated construction and demolition waste (Bekendtgørelse om anvendelse af restprodukter og jord til bygge- og anlægsarbejder og om anvendelse af sorteret, uforurenet bygge- og anlægsaffald). In Danish.

[25] Official Journal of the European Communities 2003, 2003/33/EC: Council Decision of 19 December 2002 establishing criteria and procedures for the acceptance of waste at landfills pursuant to Article 16 of and Annex II to Directive 1999/31/EC, Official Journal L 011, 16/01/2003, pp. 0027-0049.

[26] CEN/TS 14997, Characterization of waste: Leaching behaviour tests. Influence of pH on leaching with continuous pH-control, 2005, CEN/TC292.

[27] A. Zbogar, F. Frandsen, P.A. Jensen, P. Glarborg, Shedding of ash deposits, Progr. Energ. Combust. 35 (2009) 31-56.

[28] ASTM Standard D2487-10. Standard Practice for Classification of Soils for Engineering Purposes (Unified Soil Classification System), Annual Book of ASTM Standards, ASTM International, West Conshohocken, PA, 2010.

[29] O. Hjelmar, A. Johnson, R. Comans, Incineration: Solid Residues, in: Solid Waste Technology \& Management, John Wiley \& Sons, Ltd, Chichester, UK, 2010, pp. 430-462.

[30] J. Hyks, T. Astrup, T.H. Christensen, Long-term leaching from MSWI air-pollution-control residues: Leaching characterization and modelling, J. Hazard. Mater. 162 (2009) 80-91. 
[31] L. Sørum, F.J. Frandsen, J.E. Hustad, On the fate of heavy metals in municipal solid waste combustion. Part II. From furnace to filter, Fuel. 83 (2004) 1703-1710.

[32] S. Ke, Y. Jianhua, L. Xiaodong, L. Shengyong, W. Yinglei, F. Muxing, Inhibition of de novo synthesis of PCDD/Fs by SO2 in a model system, Chemosphere. 78 (2010) 1230-1235.

[33] Technical Guidance WM2, Hazardous Waste: Interpretation of the definition and classification of hazardous waste, 3rd ed., UK Environmental Agency, 2011, version 2.3.

[34] J. Reichelt, G. Pfrang-Stotz, B. Bergfeldt, H. Seifert, P. Knapp, Differences in the formation of deposits on heat exchanger surfaces in different heat and power plants, in: Proceedings Venice 2012, Fourth International Symposium of Energy from Biomass and Waste San Servolo, Venice, Italy, 12-15 November 2012, CISA Publisher, Italy, 2012.

[35] H.A. Van Der Sloot, D.S. Kosson, O. Hjelmar, Characteristics, treatment and utilization of residues from municipal waste incineration, Waste Manage. 21 (2001) 753-765.

[36] J.J. Dijkstra, H.A. Van Der Sloot, R.N.J. Comans, The leaching of major and trace elements from MSWI bottom ash as a function of pH and time, Appl. Geochem. 21 (2006) 335-351.

[37] T. Astrup, J.J. Dijkstra, R.N.J. Comans, H.A. Van Der Sloot, T.H. Christensen, Geochemical modelling of leaching from MSWI air-pollution-control residues, Environ. Sci. and Technol. 40 (2006) 3551-3557.

[38] J. Hyks, T. Astrup, T.H. Christensen, Influence of test conditions on solubility controlled leaching predictions from air-pollution-control residues, Waste Manag. Res. 25 (2007) 457466.

[39] G. Cornelis, C.A. Johnson, T.V. Gerven, C. Vandecasteele, Leaching mechanisms of oxyanionic metalloid and metal species in alkaline solid wastes: A review, Appl. Geochem. 23 (2008) 955976.

[40] CLP regulation (EC) No 1272/2008 OF THE EUROPEAN PARLIAMENT AND OF THE COUNCIL of 16 December 2008 on classification, labelling and packaging of substances and mixtures, amending and repealing Directives 67/548/EEC and 1999/45/EC, and amending Regulation (EC) No 1907/2006.

[41] Commission Regulation (EU) No 756/2010 of 24 August 2010 amending Regulation (EC) No $850 / 2004$ of the European Parliament and of the Council on persistent organic pollutants as regards Annexes IV and V, 2010.

[42] Regulation (EC) No 850/2004 of the European Parliament and of the Council of 29 April 2004 on persistent organic pollutants and amending directive 79/117/EEC, 2004. 